\title{
COMPARISON BEHAVIOR OF A LARGE TURBO MACHINE VIBRATION BETWEEN UNBALANCE AND BENT SHAFT
}

\author{
Ngo Van Thanh \\ University of Transport and Communications, No 3, Cau Giay Road, Lang Thuong Ward, \\ Dong Da District, Ha Noi, Vietnam \\ Email:ngovanthanh@utc.edu.vn
}

Received: 8 May 2015; Accepted for publication: 21 September 2015

\begin{abstract}
Recently, large capacity steam turbines have come into wider use and have been designed to perform at even higher performance specifications. As we all know, it's hard to maintain the concentricity of rotor-bearing system during operating, especially for multi-rotors within specified levels of vibration. Rotor vibration could be caused by many reasons. Mass unbalance and bent shaft are amongst the most frequently occurring of these reasons. Mass unbalance and bent shafts both give force excitation at a frequency corresponding to once per revolution. Taking a LP B rotor of a 1000 MW USC steam turbine as an example, this paper studies the lateral vibration of the LP B rotor based on finite element. Responses of mass unbalance and bent shaft are analyzed and compared.
\end{abstract}

Keywords: rotor -bearing system, mass unbalance, bent shaft, LP B rotor, lateral vibration.

\section{NTRODUCTION}

A shaft bent could be caused during shipping, installation, and operation. Bent shaft can either generate high vibration or create a lot of stress on other components during operation. Hence, catastrophic failure will result. It is therefore important to be able to recognize such a fault. For the vast majority of rotating machine, shaft bow (hog and sag) is negligible, and therefore it can be ignored for practice purposes. On long driving machines as turbo-generators in power plants or machines with long spacer shaft, bent shaft should be considered. Bend on shaft could be caused by such factors as: thermal distortion due to fast load changes-cooling or heating of the rotor, rubbing-the frictional heat produced at the site of rubbing, change of shaft 
stiffness, etc. The forcing response caused by the bend is similar to that caused by conventional mass unbalance, which is function of square of speed, though there is a slight difference in amplitude and phase angle.

In several decades, some scientists have already studied the vibration phenomenon of by shaft forcing due to an initial bend. Nicholas et al. [1] had studied unbalance response of a flexible rotor due to shaft bow through theoretical and experimental work. Parkinson et al. [2] indicated that the difference in whirl experienced by a rotating shaft due to shaft bow and mass unbalance. Shiau and Lee [3] studied the effect of residual shaft bow on the dynamic response of a simply supported single disk rotor with disk skew and mass unbalance. Edwards et al. [4] gave a method to determine the modal components of a bend and bend geometry from measure vibration signal.

In this paper the LP B rotor of a 1000MW USC (ultra-supercritical) steam turbine is studied. Turbo-generator sets with 1000MW are widely used in generation of electric power. It is large and complex rotating machine. During operation, many different forces act on it that influences the dynamic behavior of the machine. Recently, the problems on the LP steam turbine rotor become more prominent during the debugging process and in the first beginning operation. It may be caused by temperature field of the LP casing inhomogeneous [5]. Non-uniform heating can be resulted from temperature increasing or decreasing too quickly during the period of start-up or shut-down, which in turn results in rotor bending and adds centrifugal force to the machine. Figure 1 shows the structure of the LP B rotor-bearing system. The system is modeled by finite element method including gyroscopic, shear modulus and rotary inertia effects $[6,7]$. Both bearings have stiffness $\mathrm{k}_{\mathrm{xx}}=\mathrm{k}_{\mathrm{yy}}=2.45 \times 10^{9} \mathrm{~N} / \mathrm{m}$ and damping $\mathrm{c}_{\mathrm{xx}}=\mathrm{c}_{\mathrm{yy}}=3 \times 10^{3} \mathrm{~N} . \mathrm{s} / \mathrm{m}$.

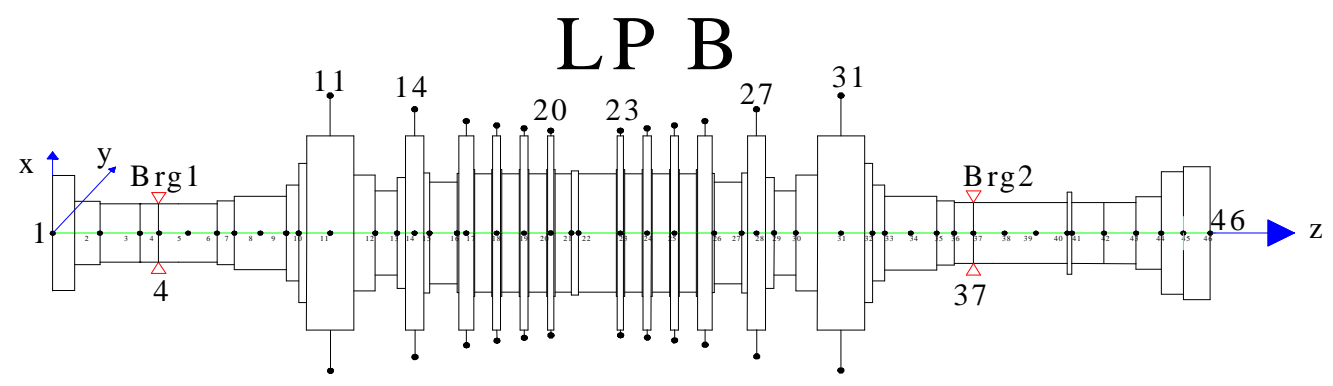

Figure 1. Modeling of a LP B rotor-bearing system.

\section{ANALYTICAL MODELING}

In general form, the equation of motion for vibration of a multiple degrees of freedom (dof) rotor - bearing system may be written as

$$
M \ddot{q}+(\Omega G+C) \dot{q}+K q=F(t)
$$


where: $q$ is a vector containing the generalize coordinate; $M$ is mass matrix; $G$ is gyroscopic matrix; $C$ is damping matrix; $K$ is stiffness matrix; $\Omega$ is rotor spin speed; $F(t)$ is generalized force.

\subsection{Unbalance response}

The vector of generalizing force acting at node $\mathrm{k}$ due to a disk offset by a displacement $\varepsilon$ and an angle $\beta$ usually represents in form [8]

$$
\left.F_{e}(t)=\Re\left(\begin{array}{c}
m_{k} \varepsilon e^{j \delta} \\
-m_{k} e^{j \delta} \\
j\left(I_{d k}-I_{p k}\right) \beta e^{j \gamma} \\
\left(I_{d k}-I_{p k}\right) \beta e^{j \gamma}
\end{array}\right\} e^{j \Omega t}\right)=\mathfrak{R}\left(\Omega^{2} b_{0 e} e^{j \Omega t}\right)
$$

where $\delta$ and $\gamma$ are the angle (when $\mathrm{t}=0$ ) of the out-of-balance force and moment vectors relative to $O x y$ axes. Taking Eq (2) into Eq (1) gives:

$$
M \ddot{q}+\Omega G \dot{q}+C \dot{q}+K q=\Re\left(\Omega^{2} b_{0} e^{j \Omega t}\right)
$$

The steady-state solution is found by assuming a response of the form $q(t)=\Re\left(q_{0} e^{j \Omega t}\right)$ ( $q_{0}$ is complex). Thus

$$
q_{0}=\left[\left(K-\Omega^{2} M\right)+j \Omega(\Omega G+C)\right]^{-1} \Omega^{2} b_{0}
$$

\subsection{Response of bent rotor}

In case of a bent rotor, the equation of motion can be written as [8]

$$
M \ddot{q}+(\Omega G+C) \dot{q}+K q_{e}=0
$$

where $\mathrm{q}_{\mathrm{e}}$ is a vector of the elastic deflections at the nodes and $\mathrm{q}$ is a vector of the total deflections at the nodes. Thus, $\mathrm{q}=\mathrm{q}_{\mathrm{e}}+\mathrm{q}_{\mathrm{b}}$, where $\mathrm{q}_{\mathrm{b}}$ denotes the vector of deflections of stationary rotor due to permanent bend. Hence, $\mathrm{q}_{\mathrm{e}}=\mathrm{q}-\mathrm{q}_{\mathrm{b}}$. Therefore, equation (5) can be written

$$
M \ddot{q}+(\Omega G+C) \dot{q}+K q=K q_{b}
$$

The geometry of the shaft bent profile is detailed definition in $[9,10]$. Because the rotor is spinning, the bend in the shaft in particular is a function of speed, then $q_{b}(t)=\mathfrak{R}\left(q_{b 0} e^{j \Omega t}\right)$ and (qb0 complex). Thus 


$$
M \ddot{q}+(\Omega G+C) \dot{q}+K q=\Re\left(K q_{b 0} e^{j \Omega t}\right)
$$

Assuming the solution of the form $q(t)=\mathfrak{R}\left(q_{0} e^{j \Omega t}\right)$, it gives

$$
q_{0}=\left[\left(K-\Omega^{2} M\right)+j \Omega(\Omega G+C)\right]^{-1} K q_{b 0} .
$$

\section{CALCULATION RESULTS}

\subsection{Case 1: Rotor supported by isotropic bearings}

\subsubsection{Unbalance response}
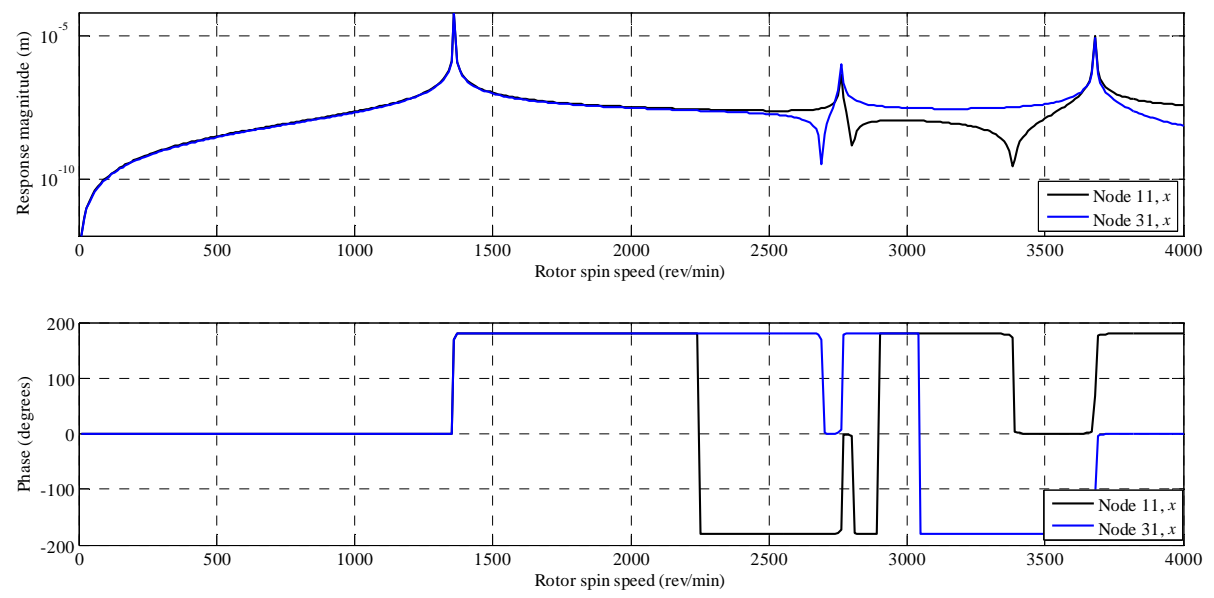

Figure 2. Unbalance response of the rotor at node 11, 31 in the $\mathrm{x}$ direction.

It's assumed that an out-of-balance of $0.001 \mathrm{~m}$ acts on the two sides of the rotor (at node 11 and node 31) in the same angular position (Fig. 1). Figure 2 shows unbalance responses and phase changes of these nodes to $x$ direction. Because of the symmetric system, the responses in the $\mathrm{x}$ direction and in the $\mathrm{y}$ direction are coincided. The responses to the out-of-balance force at the equivalent critical speeds of 1360, 2750, and $3680 \mathrm{rev} / \mathrm{min}$ get maximum values. Comparing with the rotor speeds, these speeds that are coincide with natural frequencies of the system and only forward whirl modes are exited. When rotor spins at subcritical speed range, these nodes whirl in-phase. Due to critical speeds, the phases change by approximately 1800 (because effect of damping, the phase change do not exactly by 1800). The phase changes occur at both resonances and anti resonances of the system. The phase of the node 11 reverses two times in regions $2250 \mathrm{rev} / \mathrm{min}$ and $2890 \mathrm{rev} / \mathrm{min}$ respectively. The node 31 also reverse phase in region $3050 \mathrm{rev} / \mathrm{min}$. 


\subsubsection{Response of bent rotor}

The initial deflection of the rotor is calculated by finite element method, described by Mueller and Christopher $[9,10]$. FEM model and deflection of the shaft in vertical plane are shown in Fig. 3. Forces act on shaft due to weight of the disks and gravity of the shaft.
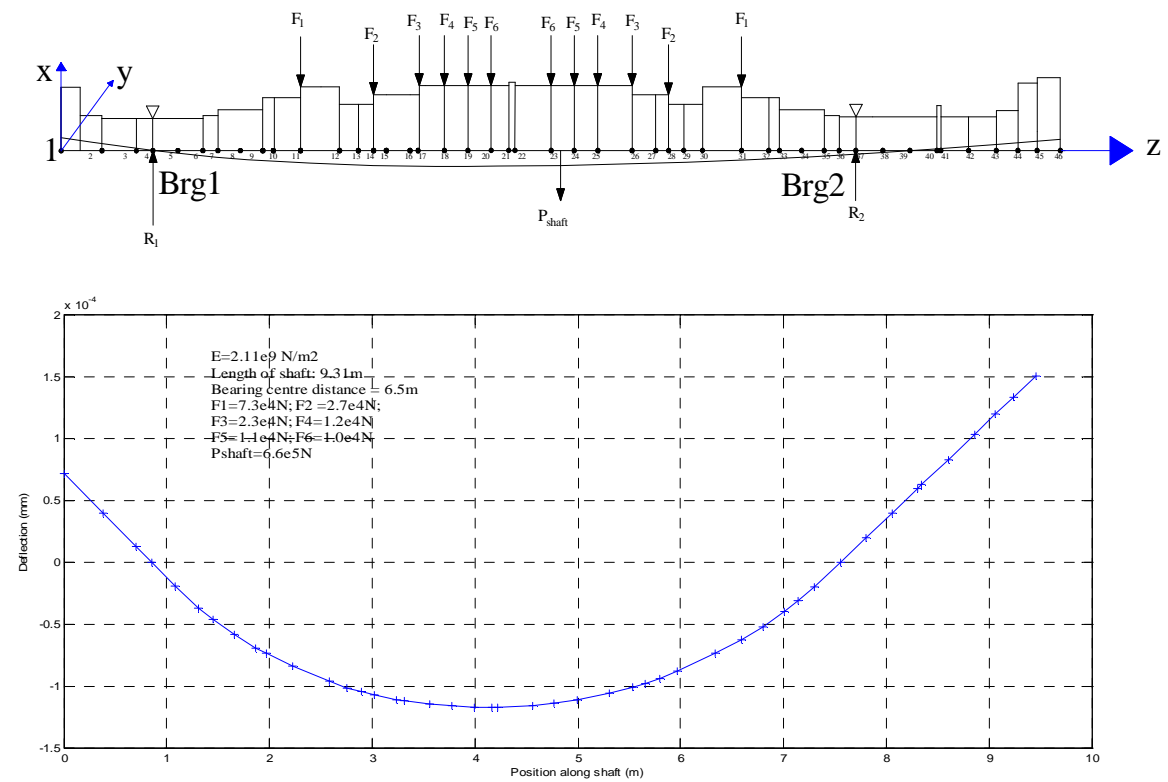

Figure 3. Stepped shaft deflection in vertical plane.
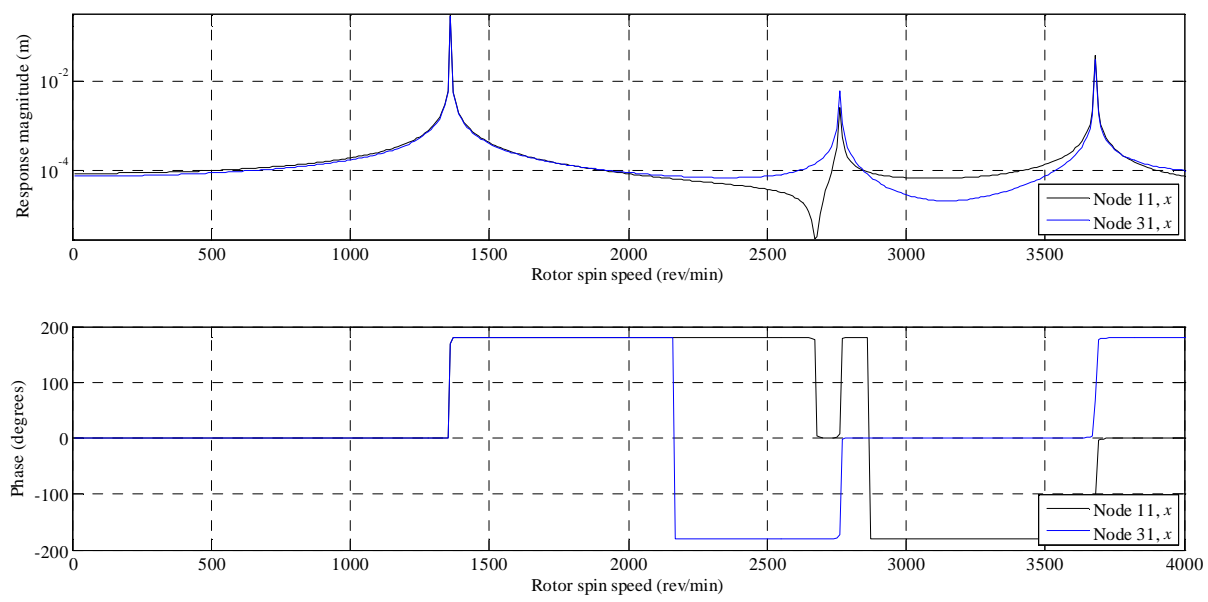

Figure 4. The response of the rotor at node 11 and node 31 in $\mathrm{x}$ direction due to a bent rotor.

Figure 4 shows the amplitude and phase response of the system at node 11 and node 31 due to initial bent of the rotor. Comparing with the response of unbalance force in Fig 2, it is shown 
that two responses are very similar. However, there are slight different at low speed and high speed of the rotor. The response of the rotor at node 11 has a zero value in region of 2670 rev/min. The response at both node 11 (and node 31) has no anti-resonance between the second and third peaks. The maximum values of the response at rotor speeds are 1360, 2750, and 3680 rev/min, respectively. It coincides with the maximum response of the rotor is excited by unbalance forces. The phase of the node 11 (and node 31) reverses in region of $2170 \mathrm{rev} / \mathrm{min}$ (2870 rev/min).

\subsection{Case 2: Rotor supported by anisotropic bearings}

This system is the same with previous system, except that the isotropic bearings are replaced by anisotropic bearings. Original stiffness of each bearing is assumed to be $\mathrm{k}_{\mathrm{xx}}=2.45 \times$ $10^{9} \mathrm{~N} / \mathrm{m}$ and will be changed, by $\mathrm{k}_{\mathrm{yy}}=2.30 \times 10^{9} \mathrm{~N} / \mathrm{m}$.

\subsubsection{Unbalance response}

The response of the system at node 11 and node 31 to out-of-balance $0.001 \mathrm{~m}$ on both disks (at node 11 and node 31) are shown in Fig. 5. The response have a maximum when rotor speeds is $1340,1360,2620,2760,3360$ and $3670 \mathrm{rev} / \mathrm{min}$. We can see that both forward and backward modes are excited. The stiffness of the system is difference in $\mathrm{x}$ and $\mathrm{y}$ directions; hence, the amplitude of whirl in these directions are difference. This illustrated in Figs. 6 and 7, respectively.
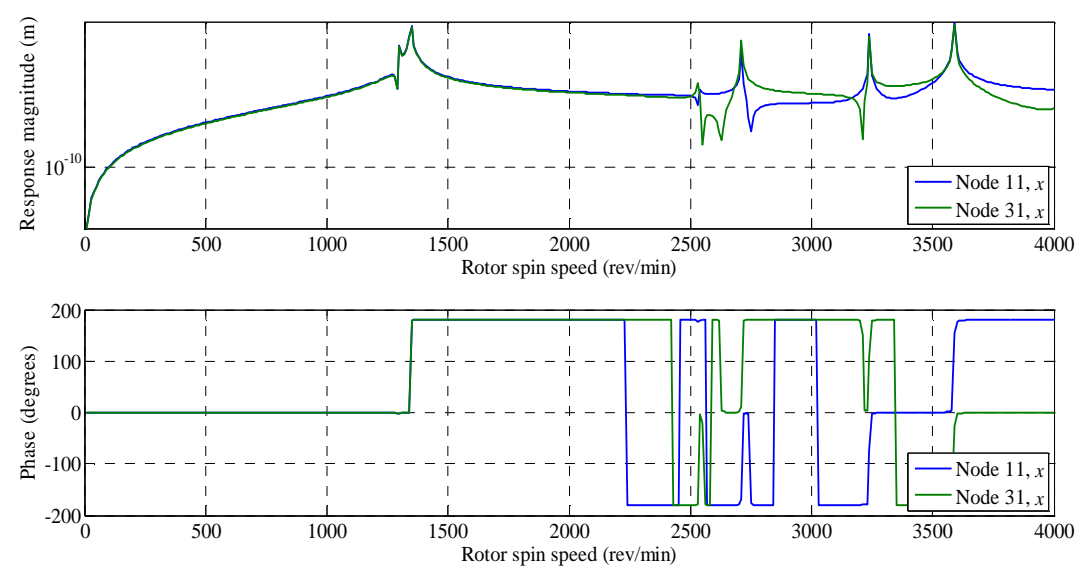

Figure 5. Responses of the rotor at node 11 and node 31 in $\mathrm{x}$ direction due to out-of-balance force at node 11 and node 31 (the length of the semimajor axis of the orbit). 


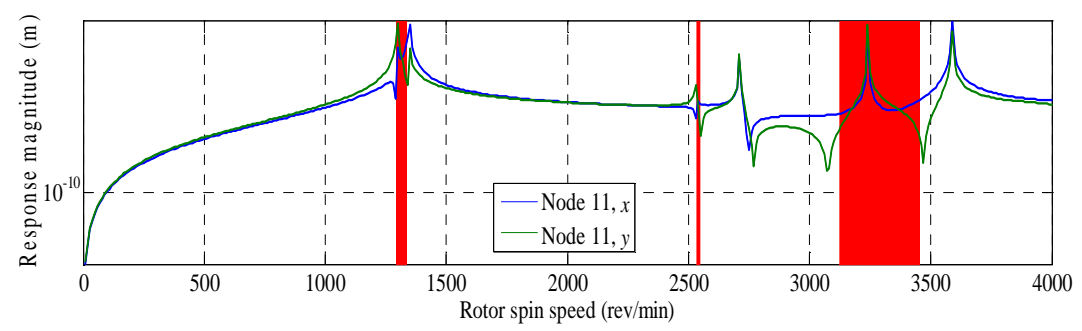

Figure 6. Response of the rotor in $\mathrm{x}$ and $\mathrm{y}$ direction at node 11 . The shaded regions indicate backward whirl.

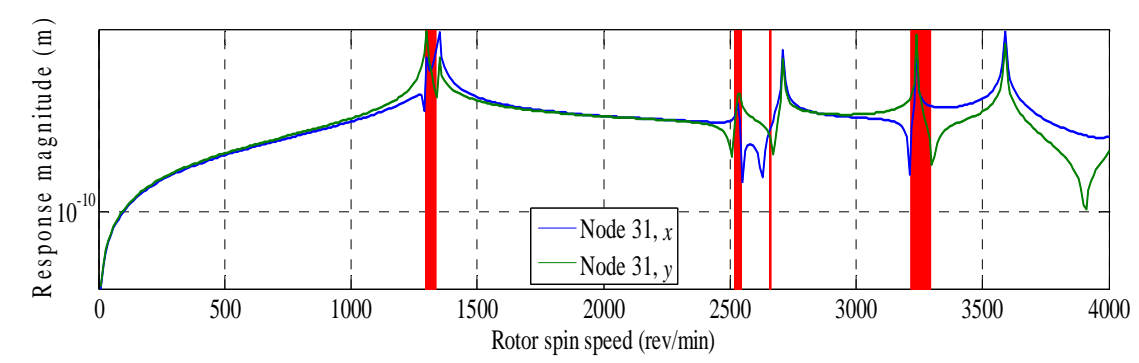

Figure 7 . The responses in $\mathrm{x}$ and $\mathrm{y}$ direction at node 31 . The shaded regions indicate backward whirl.

It can be seen that, the peaks response occur at the same rotor speed in the $\mathrm{x}$ and $\mathrm{y}$ directions. At these speeds, responses of phases are changed. The zero value of the response in $x$ and y directions occur at different rotor speeds; thus the phase of response in the $\mathrm{x}$ direction changes at a different rotor speed from that the y direction. If the phase of response in either $\mathrm{x}$ or y direction changes substantially, the direction of whirl reverse. In Fig. 6 and Fig. 7, regions of backward whirl are indicated by red regions.

\subsubsection{Response of bent rotor}

In case of bent rotor (see Fig. 3), the amplitude and phase responses at node 11 and node 31 are illustrated in Fig. 8. It is shown that there are two peaks in the response at both $1340 \mathrm{rev} / \mathrm{min}$ and $1360 \mathrm{rev} / \mathrm{min}$. Thus, both forward whirl and backward whirl are exited. When the phases of the response in $\mathrm{x}$ and $\mathrm{y}$ direction are different, the direction of whirl reverses. Fig. 9 and Fig. 10 show the response magnitude at these nodes in two directions. Red regions indicate backward whirl regions in ranges of rotor speeds. It can be seen that, at some speeds, one part of the rotor is in backward whirl whereas other is in forward whirl (mix mode). Figure 11 shows the orbits at these nodes at various rotor speeds, and the orbits are elliptical and can be forward or backward. 

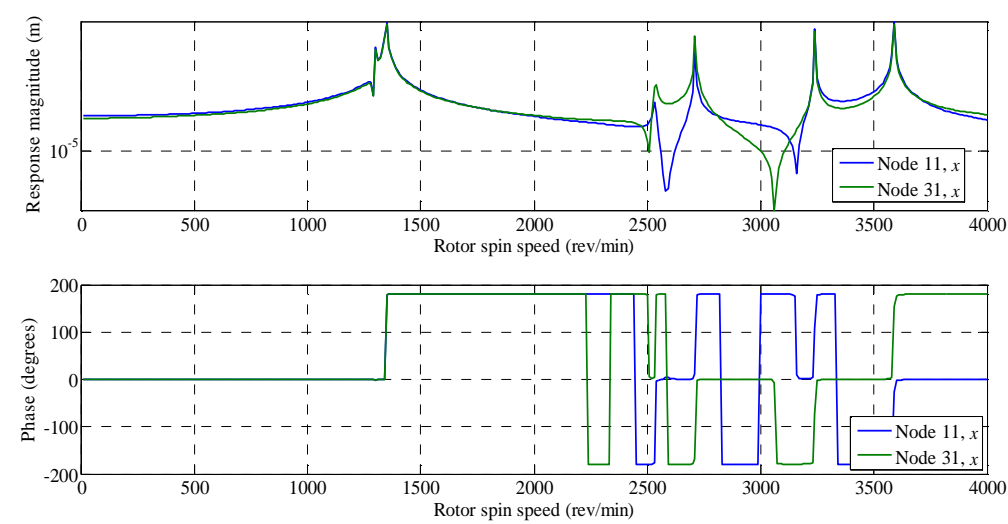

Figure 8 . The responses of the rotor at node 11 and node 31 in $\mathrm{x}$ direction due to a bent rotor.

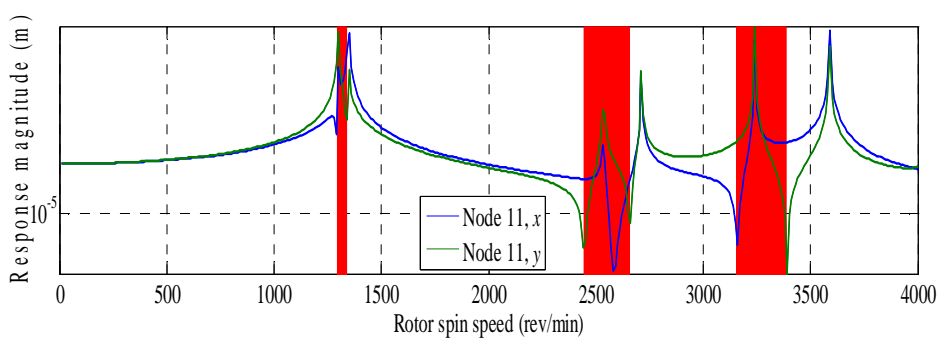

Figure 9. Response in $\mathrm{x}$ and $\mathrm{y}$ direction at node 11 due to a bent rotor.

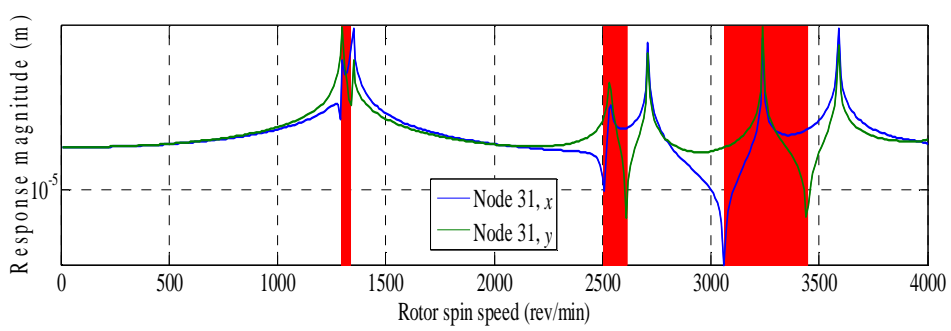

Figure 10. Response in $\mathrm{x}$ and $\mathrm{y}$ direction at node 31 due to a bent rotor.
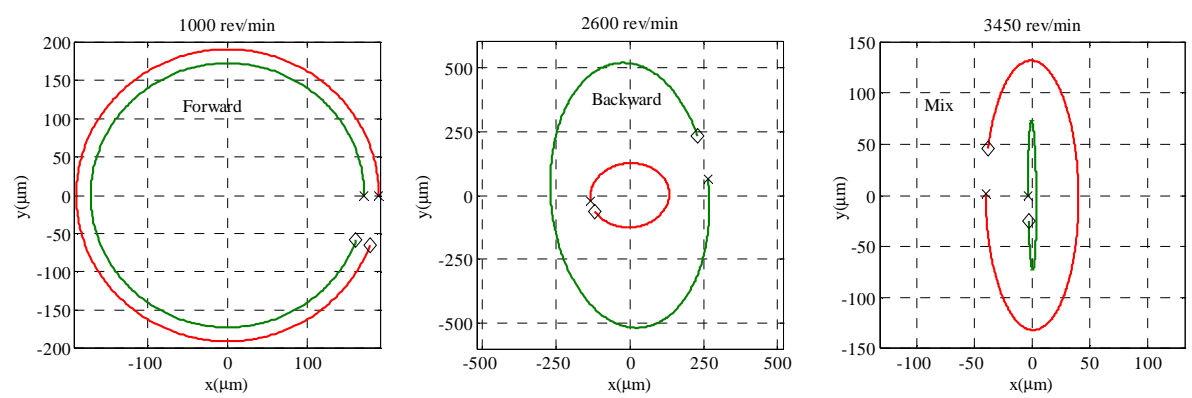

Figure 11. Whirl orbits at node 11 (red) and node 31 (green) for the bent rotor on anisotropic bearings. The cross denotes the start of the orbit and the diamond denotes the end. 


\section{CONCLUSIONS}

In this study, the dynamic vibration behavior of the LB B rotor of a 1000MW turbo-generator under unbalance forces and shaft bent is investigated. The finite element method (FEM) is applied to model the system. The results can be summarized as follows:

1) The behavior of a rotor excited by out-of-balance is almost indistinguishable from excited by a bent shaft. Comparing these responses, it is shown that the responses of them are very similar although there are still slight differences. So it's hard to distinguish bent rotor fault from out-of-balance fault.

2) The responses of the rotor in two case isotropic and anisotropic bearing systems are analyzed. In case the rotor supported by isotropic bearing, only forward modes are excited. Whereas in case of the rotor supported by anisotropic bearings, both forward and backward modes are excited.

3) As usual, as the system is linear, the effects out-of-unbalance forces and shaft bent can be studied separately. And their effects can be added up.

\section{REFERENCES}

1. Nicholas J. C., Gunter E. J., Allaire P. E. - Effect of residual shaft bow on unbalance response and balancing of a single mass flexible rotor-part 1, Journal of Engineering for Power, ASME 98 (2) (1976 ) 171-178.

2. Parkison A. G., Darlow M. S., Smalley A. J. - Balancing flexible rotating shaft with initial bend, AIAA journal 22 (5) (1984) 683-689.

3. Shiau T. N., Lee E. K. - The Residual Shaft Bow Effect on Dynamic Response of a Simply Supported Rotor With Disk Skew and Mass Unbalances, Journal of Vibration, Acoustic., Stress and Reliability in Design, ASME 111 (2) (1989) 170-178.

4. Edwards S., Lees A. W., Friswell M. I. - The Identification of a rotor bend from vibration measurement, Proceedings of the International Modal Analysis Conference - IMAC 2 (1998) 1543-1549.

5. Luo J., Liu Z., Shi Y., Xie D., Yu X. - The Research on Supporting Stiffness of LP Rotor of Ultra-supercritical Turbine, In Electrical and Control Engineering (ICECE), International Conference, 2011, pp. 1846-1848.

6. Ngo V. T., Xie D. M., Le H. D. - Finite element modeling for vibration analysis of large turbo machinery, Journal of Science and Technology 52 (5) (2014) 639-651.

7. Ngo V. T., Xie D. M., Zhang H. L., Xiong Y. H., Yang Y. - Dynamic analysis of a rig shafting vibration based on finite element, Front. Mech. Eng. 8 (3) (2013) 244 -251. 
8. Friswell M. I., Penny J. E. T., Garvey S. D., Lees A. W. - Dynamics of Rotating Machines. New York, Cambridge University Press, 2010, pp 155-200.

9. Mueller Jr. D. W. - Introducing the Finite Element Method to Mechanical Engineering Students Using Matlab, In Proceedings of the 2003 American Society for Engineering Education Annual Conference \& Exposition, (2003), Session (Vol. 3566).

10. Christopher D. W., Michael W. R. - Shaft Deflection -a Very, Very Long Example, 2013 ASEE Southeast Section Conference, 2013.

\title{
TÓM TẮT
}

\section{SO SÁNH TRẠNG THÁI DAO ĐỘNG MẤT CÂN BẦNG VÀ VÕNG TRỤC CỦA MÁY TURBINE CÕ LỚN}

\author{
Ngô Văn Thanh \\ Bộ môn Động cơ đốt trong, Khoa Co khí, Truờng Đại học Giao thông Vận tải, 3 Cầu Giấy, \\ Láng Thuợng, Đống Đa, Hà Nội
}

\section{Email: ngovanthanh@utc.edu.vn}

Những năm gần đây, turbine máy phát điện cỡ lớn được sử dụng ngày càng rộng rãi và được thiết kế để tăng hiệu suất ngày càng cao hơn. Trong quá trình vận hành, việc chăm sóc bảo dưỡng hệ thống rotor - ổ trục thường gặp nhiều khó khăn, đặc biệt là những hệ trục được liên kết nhiều rotor-ổ trục với nhau. Hệ trục này thường gặp các sự cố liên quan đến vấn đề dao động khi vận hành. Đối với dao động của hệ rotor-ổ trục kích thước lớn có rất nhiều nguyên nhân, trong đó mất cân bằng khối lượng và võng trục là những nguyên nhân thường gặp nhất. Cả hai trường hợp này đều sinh ra các lực kích thích dao động lên hệ trục. Bài báo này tác giả tiến hành nghiên cứu so sánh trạng thái dao động của LP rotor (Low Pressure rotor) của turbine $1000 \mathrm{MW}$ do mất cân bằng khối lượng và do độ võng ban đầu gây ra.

Tù khóa: hệ rotor-ổ trục, mất cân bằng khối lượng, võng trục, LP rotor, dao động ngang. 